Discussion Paper No. 97-20

\title{
Innovation and Information Technology in Services
}

Georg Licht and Dietmar Moch 


\title{
Innovation and Information Technology in Services
}

\author{
by
}

Georg Licht and Dietmar Moch

Zentrum für Europäische Wirtschaftsforschung, Mannheim (ZEW)

(Centre for European Economic Research)

May 1997

Keywords:Information Technology, Productivity, Service Sector

JEL Classification D24, L80, 033

Postadresse: ZEW Zentrum für

Europäische Wirtschaftsforschung

Postfach 103443

68034 Mannheim

Telefon: $\quad 0621 / 1235-187$

Telefax: $\quad 0621 / 1235-170$

E-Mail:_moch@zew.de 


\section{Non technical Summary}

The enduring magnitude of investment in information technology (IT) has drawn attention of many researchers, managers and policy-makers to the impacts of IT on growth and productivity. However very few studies find the desired positive impacts. While there have been considerably large investments in IT, the usual productivity indicators point to a stagnating productivity growth or even a productivity slowdown at the aggregate level. This puzzle about productivity growth - the productivity paradox - has led to intensive research. Some authors argue that the productivity paradox was based on a measurement problem. They argue that the improved quality of goods and services is not adequately considered in traditional output measures as e.g. in sales volumes leading to an underestimation of productivity growth.

Our paper deals with two explanations for the productivity paradox, using two newly available data sets for the German service sector. The argument of unobserved quality changes is supported by our results. We show that investment in information technology (IT) has a stronger effect on the quality of services than on the productivity of the IT-using firm. IT investment seems to be especially effective when innovations enhance the delivery speed and the spatial or temporal availability of service.

Apart from the problem of correct output measurement the usual measurement of IT inputs contribute to the inability to find positive impacts on the firm level. The data of the German IT survey point towards the need to differentiate between different types of IT investment. It is shown that especially the most recent generation of IT with user centered personal computing and client-server architectures is a source of productivity growth. The number of PCs used shows strong impacts whereas traditional IT like mainframes exhibit only minor productivity effect.

We conclude from our results that mismeasurement of the quality of new products and processes is one important reason for our inability to uncover the productivity effect of IT. Moreover, dividing IT-investment by the type of IT clarifies that the kind of IT a firm uses is more important for productivity growth than its quantity. In order to realize the benefits from IT investment entirely, firms have to undergo a large restructuring of business functions. In any case we expect that the bulk of the IT-related productivity growth is still to come. 


\title{
Innovation and Information Technology in Services
}

\author{
by \\ Georg Licht and Dietmar Moch \\ Zentrum für Europäische Wirtschaftsforschung, Mannheim (ZEW) \\ (Centre for European Economic Research)
}

May 1997

\begin{abstract}
The missing effect of investments of firms in information and communication technologies on productivity is studied by various recent papers (e.g. Oliner and Sichels 1994, Landauer 1995, Brynjolfsson and Hitt 1996). Several explanations are given for this missing link. Our paper deals with two of them, using two newly available data sets for the German service sector.
\end{abstract}

Using data from a survey of innovative activities in services we show that investment in information technology (IT) has a stronger effect on the quality of services than on the productivity of the IT-using firm. IT investment seems to be especially effective when innovations enhance the delivery speed and the spatial or temporal availability of service. Moreover, data of the German IT survey point towards the need to differentiate between types of IT investment. It is shown that especially the most recent generation of IT as indicated by the number of PCs used is the source of productivity growth whereas traditional IT like mainframes exhibit only minor productivity effects.

We conclude from our results that mismeasurement of the quality of new products and processes is one important reason for our inability to uncover the productivity effect of IT. Moreover, dividing IT-investment by the type of IT clarifies that the kind of IT a firm uses is more important for productivity growth what than its quantity. In any case we expect that the bulk of the IT-related productivity growth is 
still to come. In order to realize the benefits from IT investment entirely, firms have to undergo a large restructuring of business functions. 



\section{Introduction}

The enduring magnitude of investment in information technology (IT) has drawn attention of many researchers, managers and policy-makers to the impact of IT on growth and productivity. The puzzle about stagnating productivity growth has led to intensive search for solutions to the productivity paradox ${ }^{1}$. Research on the impacts of IT usually starts with the basic assumption that generally speaking computers enhance productivity. ${ }^{2}$ Various studies in recent years try to uncover the IT productivity paradox at the firm level. At best the available evidence is mixed. Brynjolfsson and Hitt (1996), Siegel and Griliches (1992), Greenan and Mairesse (1996) or Lichtenberg (1995) present data supporting a positive productivity impact of IT. Landauer (1995) argues that existing evidence in favour of productivity effects is rather weak and that existing studies suffer from severe measurement problems. In his critical review of existing literature Landauer (1995) maintains:

Computers have not contributed nearly as much to labor productivity as we had hoped, were promised, believed - or, by rights, they should. (Landauer 1995, p. xii)

Information technology has become an important field of corporate investment in all sectors. For example, the German IT market was valued at about 37 billion ECU in 1994 or about 4.5 percent of Germany's GDP. Most of these goods and services are demanded by firms. As for other types of investment, we should expect positive returns on this enormous amount of money. Moreover, the fact that companies continue to invest in IT should make us believe in positive impacts.

Investment in IT is especially important in the service sector as it is in other countries, too. This is supported by the absolute amount of money invested as well as the share of IT-investment relative to other investment. In the most dynamic service industries investment in IT is said to be larger than in manufacturing. Looking at the total IT-investment in the economy, service industries are responsible for the largest and even growing share of total expenditure on IT in the economy. But productivity growth seems to be slower in these service industries than in other sectors of the economy. In his recent book Landauer $(1995$, p. xii) states that „for the jobs most people do in service enterprises, most computer applications make work only a little more efficient". Moreover, some scholars, e.g. Gordon (1996), argue that the structural shift towards service industries is at least partly responsible for our inability to measure positive productivity effects of IT.

1 A comprehensive survey on the studies on the productivity paradox is provided by Landauer (1995).

2 See Landauer (1995) for a collection of arguments suggesting that IT improves productivity. 
This inability is even present at the microlevel as quality aspects of technical change are hard to assess especially in services.

In this paper we use new data to assess some of the problems of mismeasurement of IT productivity effects. To the best of our knowledge this study is the first using German data. Although our data set suffers from the same problem usually associated with output mismeasurement, input mismeasurement of IT, and the endogeneity of computer capital and other inputs, we offer at least some interesting stylized facts on IT in German services. Moreover, we try to enrich the literature by showing the importance to distinguish between different types of IT-technology when assessing productivity effects. Considering the enormous variety of computer equipment ranging from personal computers to mainframe computers, one should not be surprised when aggregation of computer capital matters.

We proceed as follows. In section II we briefly describe the theoretical background of productivity analysis in the service sector. In section III we assess the impact of IT on innovation in services using data from the German innovation survey. Section IV analyses the impact of the IT-structure on labor productivity using data from International Data Corporation Deutschland (IDC). We present regression results of a Cobb-Douglas model extended by IT-structure. Section V summarizes the empirical results from both data sets and draws some conclusions for future work.

\section{A short survey of recent empirical literature}

The problem of measuring productivity in the service sector has received considerable attention recently, therefore we only provide a brief summary of the theoretical background. Detailed discussions have been given, inter alia, by Griliches (1992).

One possible way to analyze these effects is to separate computer-capital from noncomputer capital as e.g. Brynjolfsson and Hitt (1996) did. They find that computer capital shows a higher rate of return. Constructing a capital stock in computers however is based on the assumption that the utility derived from an investment only depends on the nominal value. On the grounds of the assumption that IT-capital may be different from other types of capital it is hard to believe that there is no difference between the various types of IT equipment with respect to the productivity impact. A mainframe or a midrange system requires an organisation and a work flow that is different from PC based information processing.

There are other approaches trying to explain the productivity paradox, arguing that the evidence crucially depends on the availability of correct price index series for input and output. One possible explanation is that mismeasurement is based on the failure of deflating methods that do not truly capture quality changes. During the last decades, capacity and performance of computer hardware and software have 
dramatically improved. At the same time, nominal prices have either decreased slightly or just maintained their level. Recent studies on the decline of qualitycontrolled prices for personal computers (PCs) (e.g. Gordon (1990), Berndt and Griliches (1993), Nelson, Tanguay, and Patterson (1994) and Berndt, Griliches and Rappaport (1995)) have found quality-adjusted prices for PCs declining on average by 25-30 percent per year. Growing nominal investment in the presence of a decrease of quality-adjusted prices has helped to build a large IT related capitalstock in many firms. Therefore we should expect to find stronger positive impacts of IT on productivity in the present, since users now can get the same utility at a considerably lower price.

Moreover, modern IT equipment is now more easily combined with other assets of a firm as computer skills are more widely spread within the workforce. Therefore, modern IT-equipment can be better described as a general purpose technology than the standard IT-equipment of the eighties. ${ }^{3}$ So , more recent data should show stronger IT-effects than previous analyses. However, these IT-effects to some extend have to be attributed to complementary assets. Moreover, compatibility of software and hardware has been increasing since personal computers became the leading IT-technology. Network effects are of growing importance. This is confirmed by a recent study of Harhoff and Moch (1996) which implies that network effects increase with the level of compatibility. This points towards larger IT-productivity gains today than in the past.

\section{Impacts of innovation in services - some preliminary assessments using innovation survey data}

\subsection{Data on innovation in the service sector}

The first part of our empirical analysis draws on a mail survey of innovation behavior of firms in the service sector designed and carried out in 1995-1996. ${ }^{4}$ The survey's population consists on all firms with more than four employees, found in

3 Blechinger and Pfeiffer (1996) show that the computer use at the workplace increased sharply in the last two decades. In 1979 about 6\% of employees in Germany used computers. The share of computer users amount to $17 \%$ in 1985 and to $32 \%$ in 1991. The recent increase is mainly due to the diffusion of PCs. Black and Lynch (1996) draw similar conclusions.

4 The survey was commissioned by the federal ministry of science and technology $(B M B F)$. Apart from $Z E W$, other contributors include the Fraunhofer Institut für System- und Innovationsforschung (ISI) and infas (responsible for data collection). The concept of the survey and further results are presented in Licht et al. (1996). 
the records of CREDITREFORM, which is Germany's largest creditrating agency. ${ }^{5}$ This source provides data on the number of employees, industry affiliation, addresses of firms which were used to stratify the sample by sector and firm size classes as well as former West-Germany and East-Germany. The survey is restricted to marketed services and, therefore, only comprise firms from wholesale and retail trade, transport, traffic, banking, insurance, software, technical consultancy, marketing and other business related services.

About 2,900 firms participated in this voluntary survey. The overall response rate was about $26 \%$, which seems fairly reasonable when compared to response rates for other voluntary mail surveys in Germany. The response rate was above average in the banking sector, in technological services and software firms (around 30\%) and below average in wholesale and retail trade (around 24\%). Participation slightly increased with firm size. ${ }^{6}$

The survey design extends the traditional concept of innovation surveys in manufacturing as summarized in OECD's Oslo-Manual (1997) to the service sector. Topics covered in the questionnaire include (1) general information about the firm (size, industry, sales, number of employees, labor costs, exports, strategic management objectives, customers and product characteristics), (2) human capital of the firm as well as (3) investment in new physical assets and investments in information technologies. Furthermore, emphasis was put on innovative activities of firms comprising questions on $R \& D$ personnel, the acquisition of knowledge, cooperative innovation activities, linkages to public R\&D institutions, importance of various new technologies, as well as the impacts of innovation.

One basic result of our experimental approach is that innovation survey concepts developed for manufacturing are also applicable to collect information on innovative activities in the service sector if modified accordingly (see also Gault 1996). These modifications comprise (1) the inclusion of organisational innovations which seem to be much more important in services than in manufacturing, (2) the definitions of the inputs to innovation processes, and (3) the measurement of innovation output especially with respect to the quality aspects of services.

5 This seems to be the best available data source. No official register is available for service sector enterprises. The most recent data from official source on e.g. firm size or industry distribution of service sector firms refers to 1987.

6 Another 1,000 firms participated in a short telephone survey among randomly drawn nonrespondents which was conducted to reveal potential non-random selection effects depending on innovation activities. Results point to a minor bias in favour of product innovating firms. Process innovations are slightly under-represented (cf. Licht et al. 1996). 
Figure 1 depicts the weighted ${ }^{7}$ shares of product, process and organisational innovators. Product innovations are defined as new or improved services which are offered to customers. Process innovation refers to improvements in the "production process' applied internally in the firm. Organisational innovation encompasses significant changes in the organisational structure (e.g. change in the number of hierarchical layers) or in basic organisational patterns (e.g. introduction of total quality management procedures).

\section{Figure 1: Innovation in the Service Sector}

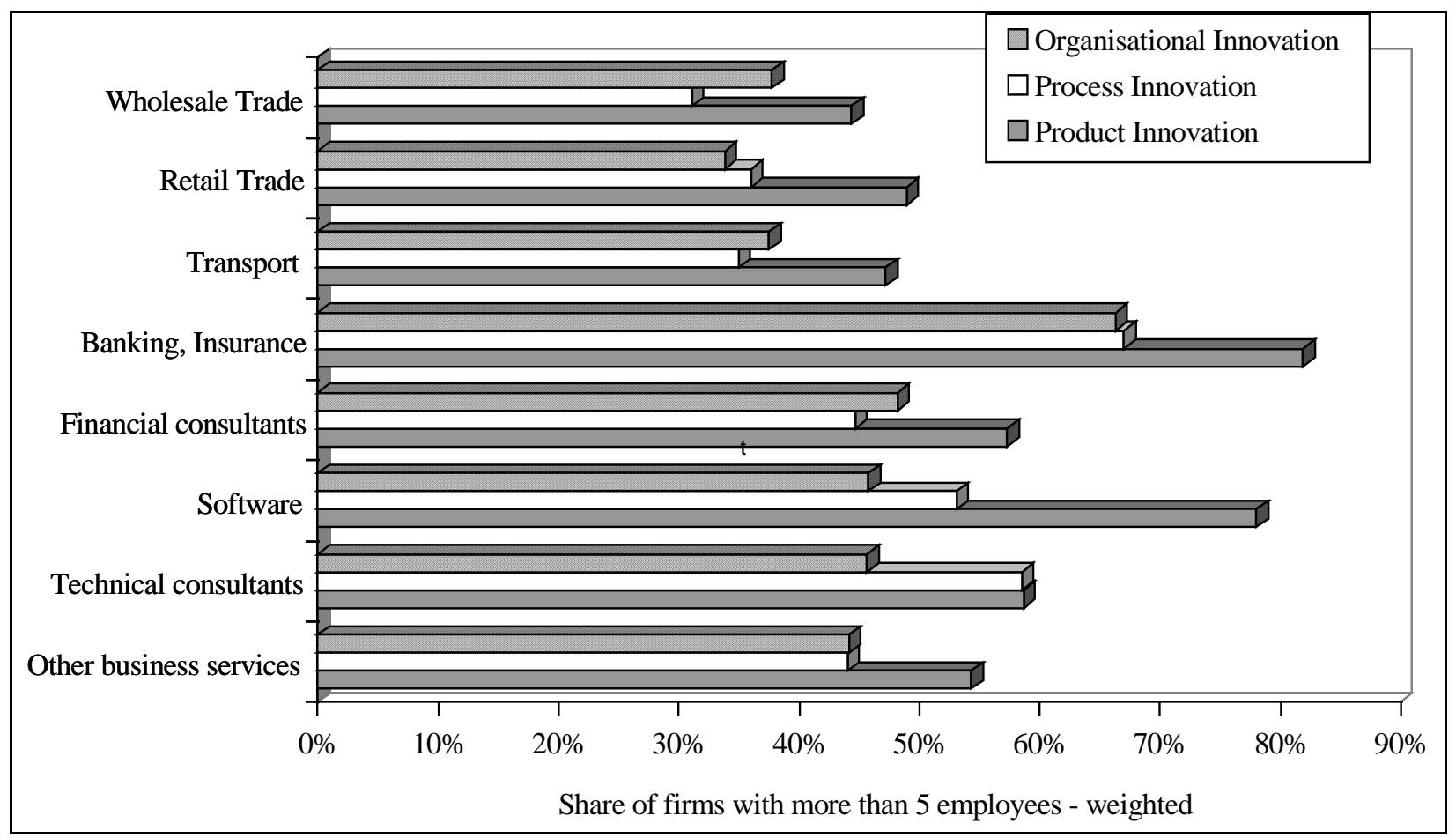

The dominant role of product innovations illustrated in Figure 1 should be taken with caution. In many cases there is no clear categorising of innovations into either 'product innovation', 'process innovation' or 'organisational innovation'. A typical example of this are 24h-cash-dispensers. Prolonged access to banking services can be regarded as a product innovation, although the actual banking product, i.e. the transfer of money, remains unaltered. As the service is not rendered through personal contact at the counter, but rather by the customer himself, this innovation could also be seen as pertaining to the process of rendering the service and thus as a process innovation. Consequently, in the following analyses we do not distinguish between product and process innovations based on the self-assessment of firms.

7 Throughout the paper we use the product of the inverse of the inclusion probability and the inverse of the response rate as weights. 
Further problems arise from the definition of research and development. The traditional concept of R\&D is mainly related to technological innovations in the manufacturing industry. The partly immaterial character of services e.g. design of an internet marketing strategy, however, requires a modification of the traditional implementation of $\mathrm{R} \& \mathrm{D}$ in firm surveys. It turned out that the understanding of $R \& D$ by service sector firms is - at least in some cases - not compatible with the traditional interpretation of $R \& D$ in $R \& D$ statistics. Nevertheless, we use the firms' answers to $R \& D$ as an indicator of a knowledge-intensive input for the generation of new products and processes. 


\subsection{Impact of Innovation in Services}

Our inability to measure productivity changes in services owing to new technologies use in service sectors may be due to the fact that unlike in manufacturing, innovation in services often is neither represented by new services nor by process improvements which increase output or decrease inputs. Innovation in service is often closely connected to the way products are delivered. E.g. technical change is connected to the number of hours during which a service can be delivered or to improvements in the spatial dimension of the services (e.g. home banking). ${ }^{8}$ Moreover, the quality of a service (e.g. user-friendliness) is another component of innovation which is usually not correctly reflected in output deflators and is, therefore, unmeasurable using traditional productivity statistics. Furthermore, it turns out that measuring innovation outputs by sales shares due to new products, which is successfully used in manufacturing, is not adequate to capture product innovation in services.

Hence, as a first step to evaluate the impact of technical change in services we use a qualitative, multidimensional approach. Firms are asked to rate different dimensions of the impact of innovations on a 5-point scale ranging from 'not at all important $(=1)$ to very important $(=5)$. These dimensions are given in Table 1 , which also delineates the share of firms which evaluate the dimension as important or very important by sector and firm size.

8 Recent studies on service sector productivity develop physical output measures (e.g. tons or kilometers for transport services) for specific service sector industries (see van Ark 1996 for further references). In addition, meaningful physical input measurement can only be derived for homogeneous output categories. Given the large heterogeneity in services the development of physical output indicators is only possible for narrowly defined industries. Developing physical output measures for the different sectors was however beyond the scope of our survey. Therefore, the use of the qualitative output assessment should be viewed as a first step towards more refined quantitative measurement of innovation output in services. 
Table 1: Dimensions of the impact of technological change in services -Part I:By industry

\begin{tabular}{|c|c|c|c|c|c|c|c|c|c|}
\hline & Overall & $\begin{array}{c}\text { Wholesale } \\
\text { Trade }\end{array}$ & $\begin{array}{l}\text { Retail } \\
\text { Trade }\end{array}$ & $\begin{array}{c}\text { Trans- } \\
\text { port }\end{array}$ & $\begin{array}{c}\text { Banking } \\
\text { Insurance }\end{array}$ & $\begin{array}{l}\text { Financial } \\
\text { Services }\end{array}$ & $\begin{array}{l}\text { Soft- } \\
\text { ware }\end{array}$ & $\begin{array}{c}\text { Consul- } \\
\text { ting }\end{array}$ & Others \\
\hline $\begin{array}{c}\text { Flexibility in adjusting } \\
\text { customer needs }\end{array}$ & 0.77 & 0.81 & 0.74 & 0.77 & 0.77 & 0.73 & 0.75 & 0.76 & 0.76 \\
\hline User friendliness & 0.53 & 0.58 & 0.40 & 0.55 & 0.74 & 0.57 & 0.67 & 0.52 & 0.59 \\
\hline Reliability & 0.71 & 0.80 & 0.66 & 0.73 & 0.62 & 0.65 & 0.77 & 0.65 & 0.70 \\
\hline Temporal availability & 0.72 & 0.75 & 0.75 & 0.64 & 0.71 & 0.71 & 0.86 & 0.63 & 0.71 \\
\hline Spatial availability & 0.43 & 0.46 & 0.45 & 0.45 & 0.47 & 0.40 & 0.43 & 0.32 & 0.42 \\
\hline $\begin{array}{l}\text { Delivery speed / } \\
\text { production speed }\end{array}$ & 0.72 & 0.82 & 0.59 & 0.68 & 0.81 & 0.67 & 0.79 & 0.73 & 0.77 \\
\hline $\begin{array}{c}\text { Fulfilling standards, } \\
\text { regulations }\end{array}$ & 0.34 & 0.39 & 0.30 & 0.48 & 0.40 & 0.31 & 0.08 & 0.28 & 0.33 \\
\hline $\begin{array}{l}\text { Fulfilling health, ecolo- } \\
\text { gical, safety regulations }\end{array}$ & 0.16 & 0.24 & 0.16 & 0.12 & 0.11 & 0.03 & 0.09 & 0.16 & 0.11 \\
\hline Output level of customers & 0.40 & 0.48 & 0.34 & 0.37 & 0.32 & 0.38 & 0.71 & 0.39 & 0.33 \\
\hline Well-being of customers & 0.35 & 0.29 & 0.52 & 0.26 & 0.18 & 0.23 & 0.18 & 0.24 & 0.31 \\
\hline Productivity of customers & 0.37 & 0.57 & 0.25 & 0.27 & 0.20 & 0.20 & 0.78 & 0.37 & 0.28 \\
\hline $\begin{array}{c}\text { Maintenance, recycling } \\
\text { properties }\end{array}$ & 0.22 & 0.34 & 0.15 & 0.14 & 0.05 & 0.06 & 0.53 & 0.29 & 0.16 \\
\hline Motivation of employees & 0.66 & 0.69 & 0.68 & 0.60 & 0.66 & 0.72 & 0.59 & 0.73 & 0.64 \\
\hline Productivity & 0.77 & 0.79 & 0.72 & 0.71 & 0.86 & 0.83 & 0.76 & 0.82 & 0.81 \\
\hline
\end{tabular}

Overall, the majority of firms views 'increasing productivity' as being important or very important. So, we should expect technical change to be reflected in the traditional (labor) productivity measurement. Still other dimensions such as 'increasing flexibility', 'increasing availability in the time dimension', 'increasing availability in the space dimension' as well as 'increasing delivery speed' are nearly equally important. Typically, items reflecting near-customer-production such as 'enhancing productivity of customers' are important for about $40 \%$ of the firms. Only a minority of firms view 'regulation aspects' (i.e. aspects concerning health care, safety, ecology, etc.) and 'increasing product life-time' as an important impact of their innovative activities. 
Table 1: Dimensions of the impact of technological change in services

-Part II: By firm size

\begin{tabular}{|c|c|c|c|c||}
\hline Flexibility in adjusting product to customer needs & $\begin{array}{c}\mathbf{5 - 1 9} \\
\text { employees }\end{array}$ & $\begin{array}{c}\mathbf{2 0 - 4 9} \\
\text { employees }\end{array}$ & $\begin{array}{c}\mathbf{5 0 - 2 4 9} \\
\text { employees }\end{array}$ & $\begin{array}{c}>=250 \\
\text { employees }\end{array}$ \\
User friendliness & 0.76 & 0.81 & 0.78 & 0.75 \\
Reliability & 0.51 & 0.55 & 0.57 & 0.56 \\
Temporal availability & 0.72 & 0.73 & 0.67 & 0.65 \\
Spatial availability & 0.74 & 0.71 & 0.68 & 0.67 \\
Delivery speed & 0.45 & 0.37 & 0.45 & 0.44 \\
Fulfilling standards, regulations & 0.70 & 0.77 & 0.76 & 0.63 \\
Fulfilling health care, ecological, safety regulations & 0.29 & 0.42 & 0.47 & 0.36 \\
Output level of customers & 0.12 & 0.24 & 0.20 & 0.28 \\
Well-being of customers & 0.39 & 0.42 & 0.39 & 0.43 \\
Productivity of customers & 0.37 & 0.27 & 0.33 & 0.27 \\
Maintenance, recycling properties & 0.36 & 0.41 & 0.39 & 0.27 \\
Motivation of employees & 0.23 & 0.24 & 0.21 & 0.17 \\
Productivity & 0.68 & 0.67 & 0.62 & 0.65 \\
\hline \hline
\end{tabular}

Moreover, it can be deduced from Table 1 that inter-industry differences seem to be more important than firm size differences. For instance, the majority of firms in the software industry expects their innovative activities to have a huge productivity impact on their customers which will also strengthen the customers' ability to increase their output. This kind of effect is absent when looking at the firm size distribution. So, the productivity effect of innovations in the software industry should be expected not within the software industry but rather in other industries.

For a more detailed analysis of this qualitative assessment of the impact of innovation in services, let us consider four dimensions of innovation in services. These dimensions are based on a factor analysis of the qualitative assessments, which is reported in Table 2. These four dimensions are: (1) Innovation enhances the quality and the range of service sector products by an increase of delivery speed or an increase of time and space availability of a service. (2) Service innovation increases the productivity of the customers of service firms. (3) Technical change in service induces productivity changes within service firms. (4) Innovation in services is made to fulfill regulations or standards. 
Table 2: Factor analysis of various dimensions of impacts of technical change in services

\begin{tabular}{|c|c|c|c|c|c|c|}
\hline \multirow[b]{2}{*}{ Variable } & \multirow[b]{2}{*}{ Mean } & \multirow[b]{2}{*}{ Std. Dev. } & \multicolumn{4}{|c|}{ Factor loadings (varimax-rotation) } \\
\hline & & & Factor 1 & Factor 2 & Factor 3 & Factor 4 \\
\hline Flexibility in adjusting product to customer needs & 4.07 & 1.02 & 0.3745 & 0.2525 & 0.2459 & 0.0071 \\
\hline User friendliness & 3.51 & 1.29 & 0.3795 & 0.2412 & 0.1681 & 0.1875 \\
\hline Reliability & 3.80 & 1.16 & 0.5449 & 0.2004 & 0.2113 & 0.2194 \\
\hline Temporal availability & 3.78 & 1.21 & 0.6935 & 0.0795 & 0.2049 & 0.2194 \\
\hline Spatial availability & 3.00 & 1.44 & 0.5612 & 0.1622 & 0.1284 & 0.1823 \\
\hline Delivery speed & 3.92 & 1.13 & 0.5057 & 0.2017 & 0.2739 & -0.0462 \\
\hline Fulfilling standards. regulations & 2.85 & 1.43 & 0.2792 & 0.1709 & 0.1215 & 0.4869 \\
\hline Fulfilling health, ecological or safety regulations & 2.03 & 1.25 & 0.0684 & 0.2228 & 0.1094 & 0.5319 \\
\hline Output level of customers & 2.97 & 1.40 & 0.1451 & 0.6675 & 0.1244 & 0.1547 \\
\hline Well-being of customers & 2.44 & 1.42 & 0.0992 & 0.2116 & 0.2743 & 0.3204 \\
\hline Productivity of customers & 2.70 & 1.45 & 0.1499 & 0.6804 & 0.0988 & 0.0993 \\
\hline Maintenance. Recycling properties & 2.09 & 1.39 & 0.1253 & 0.3027 & 0.0788 & 0.3501 \\
\hline Motivation of employees & 3.73 & 1.02 & 0.1845 & 0.0942 & 0.7169 & 0.1294 \\
\hline Productivity & 4.04 & 0.94 & 0.1775 & 0.0990 & 0.7088 & 0.0184 \\
\hline Eigenvalue & & & 3.6699 & 0.8526 & 0.6073 & 0.4330 \\
\hline Scale Reliability: Cronbach's Alpha & 0.823 & & & & & \\
\hline Number of firms: & 1869 & & & & & \\
\hline
\end{tabular}

Note: The largest factor loading of each row is shaded.

Each of the four components covers different aspects of service innovation and implies different measurement problems for traditional approaches to measuring productivity enhancing technical change in services. For instance, if new technologies (e.g. through the use of IT) help to run a 24-hour-service, the volume of sales and the cost of production might be unchanged. So, traditional productivity measurement would be unable to reflect the impact of service sector innovation which is mainly associated with dimension (1) of service innovation. Measurement problems may also arise with the elements of dimension (2) which reflect increases in service to enhance the productivity or output levels of customers. Increased competition in the software market and the steep decline of software prices, which is hardly reflected in price indices, will cause severe measurement problems with this dimension, too. Only dimension (3) is obviously easy to assess. Increased productivity of the service generation process as well as an increased motivation of employees will immediately affect traditional productivity measurements. Dimension (4), which also represents an increase of service quality, is harder to evaluate since fulfilling new legal standards or working place safety regulations will hardly be reflected in increased sales or lower factor inputs. 
These arguments imply that relating e.g. labor productivity numbers to factor inputs in services will hardly reflect the effect of technological change in services. Also, productivity effects of physical capital investment and/or knowledge input uncovered by this kind of analysis will represent a lower bound to the total effects of technological change in services.

\subsection{Assessing the Impact of Innovation Inputs on Innovation Outputs}

Based on the above assessment of the impact of innovation activities in services, it seems reasonable that the missing productivity effect of information technology can be partly explained by 'hidden' output dimensions (see e.g. Griliches 1994). Service industries absorb the lion's share of the economy-wide spendings on IT in Germany. So, at least this part of IT investment is subjected to measurement problems.

Table 3: Importance of new technologies in services by industry

\begin{tabular}{|c|c|c|c|c|c|c|c||}
\hline & $\begin{array}{c}\text { Wholesale } \\
\text { Trade }\end{array}$ & $\begin{array}{c}\text { Retail } \\
\text { Trade }\end{array}$ & Transport & $\begin{array}{c}\text { Banking } \\
\text { Insurance }\end{array}$ & $\begin{array}{c}\text { Financial } \\
\text { Services }\end{array}$ & Software & $\begin{array}{c}\text { Technical } \\
\text { Consul- }\end{array}$ \\
Software & $84 \%$ & $82 \%$ & $72 \%$ & $96 \%$ & $92 \%$ & $91 \%$ & $93 \%$ \\
Computer hardware, etc. & $83 \%$ & $85 \%$ & $84 \%$ & $96 \%$ & $96 \%$ & $90 \%$ & $95 \%$ \\
High-speed communication & $36 \%$ & $42 \%$ & $41 \%$ & $61 \%$ & $46 \%$ & $75 \%$ & $46 \%$ \\
$\quad$ networks (ISDN) & & & & & & & \\
Media-, publishing and printing & $18 \%$ & $22 \%$ & $11 \%$ & $35 \%$ & $22 \%$ & $39 \%$ & $38 \%$ \\
technologies & $38 \%$ & $37 \%$ & $80 \%$ & $4 \%$ & $8 \%$ & $7 \%$ & $14 \%$ \\
Transport technologies, logistics & & & & & \\
Measurement, control technologies & $24 \%$ & $27 \%$ & $10 \%$ & $9 \%$ & $0 \%$ & $16 \%$ & $32 \%$ \\
Medical technologies & $7 \%$ & $10 \%$ & $2 \%$ & $1 \%$ & $1 \%$ & $8 \%$ & $5 \%$ \\
$\quad$ Biotechnology & $10 \%$ & $6 \%$ & $2 \%$ & $1 \%$ & $0 \%$ & $1 \%$ & $2 \%$ \\
Environmental technologies & $31 \%$ & $27 \%$ & $33 \%$ & $5 \%$ & $7 \%$ & $13 \%$ & $37 \%$ \\
$\quad$ New materials & $28 \%$ & $12 \%$ & $12 \%$ & $1 \%$ & $4 \%$ & $3 \%$ & $21 \%$ \\
\hline
\end{tabular}

Note: The table gives the shares of innovative firms which state that these technologies are important for their innovative activities. The list of these technologies was given in the questionnaire.

As shown by our survey computers, hardware, software, and modern telecommunication network technologies represent important technologies for the overwhelming majority of firms. Nearly all firms that introduced product, process or organisational improvements, view information and telecommunication technologies as a key element for innovative activities (see Table 3). For this reason our ability to measure the productivity effect of investment in information 
technologies will be clouded by missing some output dimensions of service sector innovation.

To assess this hypothesis of unmeasured output generated by IT, we will use the qualitative assessment of innovation activities and relate these output indicators to input factors. We interpreted these qualitative assessments as an indicator for a change in output characteristics rather than for the level of output. So, we relate this change in output to the change in inputs which is given by the investment in physical capital, investment in information technologies, R\&D expenditure , as well as investment in the capabilities of employees ('training'). We normalise these different types of input by the number of employees. Furthermore, we use additional controls for the level of human capital, industry, firm size, and region. ${ }^{9}$ Therefore, our empirical model is given by:

$$
D_{i}=\alpha_{i} I+\beta_{i} I T+\delta_{i} R \& D+\gamma_{i} E+\sum_{j=1}^{3} \lambda_{j, i} S+\sum_{j=1}^{7} \kappa_{j, i} Z+\mu_{i} G+\varepsilon_{i}
$$

where

$\mathrm{D}_{\mathrm{i}} \quad \mathrm{i}$-th dimension of output of innovation activities in 1993-1995

I investment in non-IT physical capital per employee 1994

IT investment in information technologies per employee in 1994

R\&D share of R\&D employees in total employment in 1994

E expenditures on training and professional education per employee in 1994

$\mathrm{S} \quad$ firm size dummies ${ }^{10}$

$\mathrm{Z} \quad$ industry dummies ${ }^{11}$

G East-German firm.

If the argument of unmeasurable output of information technology is correct for service industries, we should expect no or only a weak correlation between the dimension of innovation output which refers to the productivity of the firm at hand and IT-investment.

9 Additional controls for export status or the introduction of a full set of interaction terms have been tried without affecting our basic conclusion.

10 We use four different size classes: $1-19 ; 20-49 ; 50-249$; >= 250 employees.

11 We distinguish 8 different industries in the service sector:wholesale trade, retail trade, transport, banking and insurance, financial services, software, consulting 
Table 4: Relating factor input to qualitative assessments of innovation impacts in services Order probit regressions*

\begin{tabular}{|c|c|c|c|c|c|}
\hline & $\begin{array}{l}\text { Investment (excl. } \\
\text { IT) per employee }\end{array}$ & $\begin{array}{l}\text { IT-Investment } \\
\text { per employee }\end{array}$ & R\&D-Intensity & $\begin{array}{c}\text { Training expenses } \\
\text { per employee }\end{array}$ & $\begin{array}{l}\text { No. of firms/ } \\
\text { chi2(16)-test }\end{array}$ \\
\hline \multirow{2}{*}{$\begin{array}{l}\text { Flexibility in adjusting } \\
\text { to customer needs }\end{array}$} & 0.0077 & 0.0142 & 0.0034 & 0.0275 & 1196 \\
\hline & 5.35 & 2.05 & 0.73 & 1.55 & 71.20 \\
\hline \multirow[t]{2}{*}{ User friendliness } & 0.0032 & 0.0187 & 0.0065 & 0.0133 & 1186 \\
\hline & 2.50 & 3.00 & 1.48 & 0.84 & 73.06 \\
\hline \multirow[t]{2}{*}{ Reliability } & 0.0027 & -0.0002 & 0.0186 & 0.0143 & 1189 \\
\hline & 2.08 & -0.04 & 3.96 & 0.87 & 65.42 \\
\hline \multirow[t]{2}{*}{ Temporal availability } & 0.0028 & 0.0197 & 0.0073 & 0.0670 & 1178 \\
\hline & 2.09 & 2.93 & 1.61 & 3.89 & 99.91 \\
\hline \multirow[t]{2}{*}{ Spatial availability } & 0.0080 & 0.0107 & 0.0001 & 0.0544 & 1190 \\
\hline & 6.01 & 1.67 & 0.03 & 3.37 & 101.66 \\
\hline \multirow[t]{2}{*}{ Delivery speed } & 0.0051 & 0.0228 & 0.0065 & 0.0323 & 1190 \\
\hline & 3.62 & 3.34 & 1.41 & 1.89 & 101.66 \\
\hline \multirow{2}{*}{$\begin{array}{l}\text { Productivity of } \\
\text { customers }\end{array}$} & 0.008 & 0.0028 & 0.0165 & 0.0553 & 1168 \\
\hline & 6.29 & 0.46 & 3.74 & 3.30 & 280.29 \\
\hline \multirow{2}{*}{$\begin{array}{l}\text { Output level of } \\
\text { customers }\end{array}$} & 0.0078 & 0.0015 & 0.0142 & 0.0571 & 1176 \\
\hline & 6.02 & 0.25 & 3.30 & 3.49 & 156.99 \\
\hline \multirow[t]{2}{*}{ Productivity } & 0.0028 & 0.0093 & 0.0147 & 0.0412 & 1191 \\
\hline & 2.06 & 1.38 & 3.10 & 2.42 & 52.26 \\
\hline \multirow[t]{2}{*}{ Motivation of employees } & 0.0040 & 0.0089 & 0.0164 & 0.0585 & 1190 \\
\hline & 2.92 & 1.35 & 3.61 & 3.50 & 67.12 \\
\hline \multirow{2}{*}{$\begin{array}{l}\text { Fulfilling health, ecolo- } \\
\text { gical, safety regulations }\end{array}$} & 0.0089 & 0.0003 & 0.0110 & 0.0489 & 1165 \\
\hline & 6.71 & 0.04 & 2.48 & 2.97 & 126.23 \\
\hline \multirow{2}{*}{$\begin{array}{l}\text { Fulfilling standards. } \\
\text { regulations }\end{array}$} & 0.0093 & 0.0102 & 0.0130 & 0.0246 & 1178 \\
\hline & 7.02 & 1.60 & 3.01 & 1.55 & 113.25 \\
\hline \multirow{2}{*}{$\begin{array}{c}\text { Maintenance, recycling } \\
\text { properties }\end{array}$} & 0.0037 & -0.0155 & 0.0080 & 0.0280 & 1157 \\
\hline & 2.69 & -2.13 & 1.78 & 1.68 & 124.75 \\
\hline \multirow[t]{2}{*}{ Well-being of customers } & 0.0087 & -0.0054 & 0.0000 & 0.0614 & 1172 \\
\hline & 6.64 & -0.85 & 0.00 & 3.75 & 107.60 \\
\hline
\end{tabular}

* $\mathrm{t}$-values are given below the regression coefficients.

Note: The model also includes controls for human capital level, industry affiliation, firm size, and region. Results are not reported but available upon request. 
Given the qualitative nature of the output dimension (5-point Likert-scale), we use ordered-probit-models. The results are reported in Table 4 where each row represent an ordered-probit-regression ${ }^{12}$ The items are grouped with respect to their association with the four dimensions of innovation outputs in services.

First, we should note that the individual ratings are subjective in nature. So, we should not be surprised that the overall explanatory power of the models will be driven downwards by this subjective assessment. However, the results of our exercise are rather robust with respect to the inclusion of additional variables which probably help to explain the subjective nature. We took export shares, ownership or more disaggregated industry classifications into account, but our basic conclusions remain unchanged. Second, the time dimension of our exogenous and endogenous variables does not fit perfectly. The expenditure variables refer to the year 1994 only, whereas the endogenous impact variables refer to an 'average' over the threeyear time period (1994-1996). It still seems reasonable to argue that the subjective assessments are mainly motivated by the respondents' recent experiences. Given that our endogenous variable reflects assessments at the time of the survey (October 1995 to April 1996), a reasonable time span is available, so that the respondents have really learned about the impact of the investment decisions in 1994.

In summary, we found significant effects of IT-investment on flexibility in adjusting products to customer needs, user-friendliness of the products, the temporal availability of services (e.g. 24h cash dispensers), and delivery speed (e.g. internet, improved logistics), but only a weak impact of IT-investments per employee on the productivity of the firm. We even found a negative correlation between the maintenance or recycling properties and the intensity of IT-investment. Thus, we can conclude that the effects of IT-investment on innovation in services are reflected mainly in product quality improvements. Direct productivity impacts or quality improvements of the production process for services seem to be less affected by IT.

On the other hand, non-IT physical investment (calculated as total investment minus IT-investment) bears a significantly positive sign when compared to the dimensions of innovation output. Particularly strong associations are found for enhancing the flexibility in adjusting products to specific customer needs, fulfilling legal standards and regulation, and with respect to the productivity of customers.

12 In order to save space we only report the coefficients and t-values for the variables which are used to test our hypothesis. In additon to the results reported, we find significant inter-industry and inter-regional differences. Size class effects play only a minor role. 
Moreover, R\&D efforts seem to be relevant to several features of service innovations. ${ }^{13}$ Not surprisingly, $R \& D$ enhances the productivity of the firms at hand as well as the productivity of customers. $R \& D$ is also associated with unmeasureable components like reliability of the service and the ability to fulfill various regulatory requirements. Similarly, firm's expenditures on human capital enhance productivity and the quality of services.

We further test the validity of these results by considering potential complementarities between the factor inputs and by taking into account unmeasured input dimensions which lead to correlations between the error terms in the regression models for different output dimensions. We shortly will review these results.

If there are complementarities between IT-investment on the one hand and non-ITinvestment, R\&D intensity or human capital intensity on the other hand, our model specification will fail to uncover these effects. To account for this possibility, we also run regressions with additional interaction terms of IT-investment and the other forms of investment. And indeed, we find especially strong associations between the interaction term (= IT-investment $*$ non-IT-physical investment $)$ and the productivity impact of service innovation. This is also true, although to a smaller extent, with respect to customer's productivity, as well as the temporal and spatial availability of service innovations. However, we failed to uncover complementarities between investment in human capital (measured by expenditures on training) and IT-investment. ${ }^{14}$ These results highlight another measurement problem: Our ability to measure the productivity effects of IT is also affected by the degree of complementarity between physical non-IT-investment and IT-investment, so that some productivity effects of IT are probably reflected in the measured effects of non-IT-investment.

Using factor scores derived from a factor analysis as indicators of the output dimension of service, innovation does not alter our basic conclusion (results reported in appendix 2). IT enhances the quality of services but exhibit only a minor effect on the productivity. Training and R\&D affect the productivity as well as the ability to cope with regulative requirements and standards.

13 Remember that the interpretation of ' $R \& D$ ' by the responding firms is only partly compatible with the standardised R\&D definitions as given in the FRASCATI manual. R\&D should be best interpreted here as efforts on near-market product development.

14 When asked for medium term employment expectation by skill level, the respondents expect a larger skill shift if they invest more in IT. So, complementarities between IT and human capital are present in the long-run and with respect to general human capital. Training expenditures used here reflect firm-specific human capital. 
Although the qualitative assessment can be used to shed light on productivity measurement problems in services it remains questionable whether this will be helpful to find a link between the inputs into knowledge generating processes and the output effects of technological change. Qualitative assessments are basically subjective in nature. And individual assessments on the dimensions of impact of new technology will hardly be an adequate substitute for measuring 'hard facts'.

To summarize the results so far, we should keep in mind that IT-investment seems to be often associated with quality aspects of service innovations. Therefore, there is indeed the danger that labor productivity or total factor productivity will not adequately reflect the true impact of IT. The productivity paradox with respect to IT in services can at least partly be attributed to measurement problems.

\section{Productivity effects of information technology}

The discussion of IT impacts is to a large extend a discussion of measurement issues. These measurement problems may have contributed to the productivity paradoxon. While managers often justify their investment decisions by expectations of productivity gains, studies on industry level have not confirmed these expectations yet. However, after decades of investing in IT and learning how to use IT, we should find some impact of IT on productivity. Even if we can not identify them at industry level, they should at least be visible at the firm-level.

\subsection{Data on information technology}

The second part of our empirical analysis is based on the German Information Technology Survey ${ }^{15}$. This data set is a unique source of information on IT-use in Germany containing information on the different kinds of IT capital used. For this study we use only a part of the information that has been provided by International Data Corporation Germany (IDC). About 3800 IT managers or managing directors of establishments from all sectors voluntarily participated in the telephone interviews in January and February 1996.

In this study we use data from 791 establishments of all industries, including 474 establishments 16 from the service sector. We will make extensive use of variables representing the various kinds of computer hardware used. The data distinguish

15 We gratefully acknowledge IDC for providing us with the data and helpful information. IDC is conducting market research, analysis and consulting for the information technology industry.

16 This dataset provides detailed information about the IT-equipment in use and the spendings. Unfortunately only about $30 \%$ of the companies provide information on their sales. Appendix 3 shows some decriptive statistics on the service sector firms in the IT-survey 
between four different types of computer terminals. There are terminals that are either connected to a mainframe ${ }^{17}$ (e.g. IBM 3090) or to a midrange computer (e.g. IBM AS/400). There are also stand-alone UNIX workstations and personal computers that are either IBM-compatible or Apple compatible. We use the number of workplaces per employee that existed by the end of 1995 as a proxy for the ITintensity. In our opinion, the number of terminals is closer to the real use of IT than aggregations of memory or MIPS installed, since from these values we do not know how much of the computing power is really used. Besides that, it is hardly possible to get detailed and reliable information on installed capacity and computing power in a telephone interview.

Furthermore, the data set contains the number of employees and sales that were used to calculate labor productivity. The dataset, however, did not contain information on capital stock and materials used originally. We constructed firm specific values of these variables using the disaggregated national accounts data on sector specific ratios of capital stock and materials per employee of the year $1992^{18}$.

Since the data were collected in telephone interviews, it seems to be quite sensible that there are unreliable or crude data resulting in outliers because interviewees provide data immediately during the interview. Therefore, the estimation techniques used should be robust against outliers.

\subsection{Estimating productivity of IT}

Our attempt to estimate the productivity impacts of IT starts from a Cobb-Douglas production function linking sales(Y) with labor (L), capital (K) and material (M) ${ }^{19}$.

$$
Y=A * K^{\alpha} * L^{\beta} * M^{\gamma}
$$

We impose constant returns to scale by setting $(\alpha+\beta+\gamma=1)^{20}$. One possible source of the productivity paradoxon probably is related to the construction of the IT-related capital stock. If the aggregation of IT capital does not distinguish between different types of IT, IT capital possibly does not reflect the 'true value' of

17 Only terminals connected to a mainframe located within the establishment were considered.

18 Using capital stock of the year 1992 ensures that there is less double counting of IT-capital in the capital stock since the IT-equipment is usually replaced after 3-4 years.

19 Brynjolffson also uses a Cobb-Douglas to estimate productivity impacts of IT.

20 Please note that the coefficients used here are different from those used in the previous section. 
IT, hence does not attribute the impacts to the real productivity boosters. Therefore, our model allows different productivity values for different types of IT equipment.

In principle IT affects the marginal productivity of all factors of production. Moreover, expenditures related to IT are 'hidden' in all factor inputs. The book values of IT are included in K. The IT expenses on software and services and the leasing rates contribute to $\mathrm{M}$. Labor input comprises both, workers who are able to use computers and workers who are not. Recent empirical work by Autor et. al. (1996) points to higher wages of computer users as well as to shifts in skill structure of labor due to computerisation. Given the data constraints, we assume that the marginal productivity of intermediate inputs ('Materials') and labor is the same for IT related and non-IT related labor and material input. Note, that this may lead to an overestimation of the effect of IT on the marginal productivity of IT capital since all differences between IT users and non-users are forced to enter our empirical model via the capital stock. Our model, therefore, is given by:

$$
\ln \frac{Y^{\prime}}{L^{\prime}}=\ln A^{\prime}+\alpha \ln \frac{K^{\prime}}{L^{\prime}}+\gamma \ln \frac{M^{\prime}}{L^{\prime}}+\sum_{i} \lambda_{i} \ln \frac{I T_{i}}{L^{\prime}}
$$

\subsection{Productivity Impact of Information Technology in Services}

The distinction between IT and non-IT parts for each production factor is possible for capital and material, but is impossible for the labor input because it would not be sufficient to count IT-personal. Since IT has been diffusing widely within companies, the business process has to be analyzed by looking at the business functions of all employees. Given data constraints, we follow the traditional paths distinguishing IT capital and non-IT capital and neglecting IT shares in the other factors. Using the value of the capital stock, however, may lead to biased results due to measurement problems. First of all, it is difficult to assess the IT used by companies. If we take the book value of computers owned, we face a bias arising from different ownership concepts. A company may buy or rent a computer which is especially a problem with mainframe computers. In the first case we would find the value of the computer in the business records i.e. capital whereas in the second case the leasing rates would add to the materials resp. intermediate inputs.

Second, we expect the choice of products and brands to have a strong influence on the price and thus the investment whereas we expect the productivity of an employee to be independent from the brand chosen. Third, technical change is very fast in the IT industry. Therefore the construction of computer capital requires quality adjusted price indexes which are hard to obtain for all different types of IT equipment. Fourth, it is - at least in Germany - not allowed to activate software and IT services in the records which makes it difficult to track the IT capital over time. The most important argument, however, to use IT-equipment rather than on ITcapital as a type of capital in production measurement is that this would imply equal 
benefits of different technologies within the wide space of IT-Goods. In such a model, $5000 \mathrm{DM}$ spent on an additional mainframe terminal would have the same effect on productivity as the same amount on a high-powered PC including access to a mainframe. If it is the specific technology used that matters, more disaggregated production functions are needed.

The IT-equipment is represented by the number of workplaces equipped with access to computing services. We distinguish three types of computing devices: First, there is centralized computing with terminals that usually provide a character based display that is either connected to a mainframe or to a midrange system. In both cases the processing is done centrally in a computing center. Second, localized UNIX computing with a stand-alone UNIX workstation. Usually a high powered device that has proprietary hardware and requires administrative services. Third, personal computers that are either IBM-compatible or Apple systems that provide local computing power and usually a graphical user interface.

Therefore, our empirical model is given by ${ }^{21}$ :

$$
\begin{aligned}
L P & =A+\alpha K+\gamma M+\lambda_{1} \text { TERM }+\lambda_{2} \text { UNIX }+\lambda_{3} P C+ \\
& +\sum_{j=1}^{3} v_{j, i} S+\sum_{j=1}^{6} \kappa_{j, i} Z+\varepsilon_{i}
\end{aligned}
$$

where:

LP Labor Productivity22

K $\quad \log$ (physical capital per employee )

M $\quad \log$ (materials per employee)

TERM $\log$ (terminals per employee)

UNIX $\log$ (standalone UNIX workstations per employee)

$\mathrm{PC} \quad \log (\mathrm{PCs}$ per employee $)$

$\mathrm{S} \quad$ firm size dummies

$\mathrm{Z} \quad$ industry dummies ${ }^{23}$

21 Please note that the data taken from national accounts (i.e. material and capital intensity by sector) respond to the year 1992.

${ }^{22}$ Labor productivity is defined as log (sales per employee). In the banking industry we use balance sheet total as output and for insurance companies we use total premia income

${ }^{23}$ Since we have less observations than in the innovation survey, we join the former groups of wholesale trade and resale trade, transport and financial services, software engineering and of 
consulting. The regression on all sectors include 3 additional dummies for non-service sector industries. 
Table 5: Labor productivity and IT-equipment - LAD ${ }^{24}$ regression estimates

\begin{tabular}{|c|c|c|c|c|}
\hline \multirow[b]{2}{*}{ log (Labor productivity) } & \multicolumn{2}{|c|}{ All Sectors } & \multicolumn{2}{|c|}{ Service Sector } \\
\hline & Coef. & t-value & Coef. & t-value \\
\hline $\log ($ Capital $) *$ & 0.2208 & 3.13 & 0.1780 & 1.98 \\
\hline $\log ($ Material $) *$ & 0.2564 & 2.65 & 0.3147 & 2.95 \\
\hline $\log ($ Terminals $) *$ & 0.1451 & 3.11 & 0.0507 & 0.81 \\
\hline $\log ($ UNIX workstations)* & 0.0938 & 1.79 & 0.0526 & 0.67 \\
\hline $\log (\mathrm{PCs} \text { and MACs })^{*}$ & 0.3229 & 11.13 & 0.3260 & 8.48 \\
\hline \multicolumn{5}{|c|}{ test statistics } \\
\hline Size Dummies & $\mathrm{F}(3,77$ & & \multicolumn{2}{|c|}{$\mathrm{F}(3,459)=2.97$} \\
\hline Industry Dummies & $\mathrm{F}(7,77$ & & \multicolumn{2}{|c|}{$\mathrm{F}(4,459)=52.88$} \\
\hline F-test (whole regression) & $\mathrm{F}(17,77$ & & \multicolumn{2}{|c|}{$F(14,459)=39.04$} \\
\hline
\end{tabular}

* Per employee

Please note, all regression models include industry dummies, a dummy for EastGerman firms, and firm size dummies. Moreover, regression models for all firms include some zero-expenditure values. The undefined log-values for those cases are substituted by the lowest positive expenditure values and an additional dummy variable is added to the specification taking the value of one in those cases.

The interpretation of our regression results strongly depends on the question whether there exists double-counting for IT or not. We can approximate the effects by considerung two extreme cases: In the pessimistic case there does not exist any double counting. That means, IT is not included in the capital stock $\mathrm{K}$ at all. In this case the estimated coefficients $\lambda_{\mathrm{i}}$ should be significantly greater than $\alpha$ to exhibit above average productivity gains for IT against other types of capital. In the optimistic case there is full double-counting of IT. Then the $\lambda_{i}$ represent the additional productivity of IT compared to the average capital and it will be sufficient for $\lambda_{\mathrm{i}}$ to be significantly greater zero.

Strikingly, PC equipment shows in both regressions a very high correlation with labor productivity whereas the effect of other IT-equipment is low or not existing. Looking only at service industries, we do not find any significant impacts of terminals and UNIX workstations. So from the optimistic point of view, we can 
confirm positive impacts in the service sector for the PC technology only. Exploring the pessimistic case, we start for each type of IT with the hypothesis that its impact on productivity is the same as the average impact of capital. These hypotheses are rejected by an F-test. Testing mainframes to capital shows $F(1,459)=1.36$. The coefficient of terminals is less than $\alpha$, indicating the productivity impacts of mainframes being lower than for other capital. The hypothesis for PCs is also rejected by $F(1,459)=2.15$. PCs, however, have a higher coefficient than capital, thus having higher productivity impact. The results of these exercises for all sectors are pointing the same direction with $\mathrm{F}(1,773)$ being $1.72,2.08$ and 0.83 for PCs, UNIX and terminals, respectively.

One might argue that PC investment may be so large, because firms do not know the real cost of a PC. Companies armed with PCs may face higher unobserved costs for maintaining their IT-infrastructure compared to Mainframe users that can calculate their facilities' costs pretty well. Usually, the establishments do not account for the cost of their workforce spending a considerable part of their working hours on keeping the PC at work. In combination with low prices managers may tend to buy PCs more easily than other IT-hardware. So, our estimate not only captures a PC effect but also the effect of the complementary know-how provided by the employees.

Mainframe environments, however, are complex systems that require big staff and long-term projects. They exhibit, therefore, a very conservative influence on the development of organisations. In a world with markets speeding up, they do not allow their users to adapt to different conditions in time. PC-Users can react very fast to information needs. E.g. spreadsheets and databases allow user defined data aggregations which would on a mainframe environment either require tedious programming or the printing and manual processing of long lists.

Another important explanation why the influence of PCs is so large, is provided by the theory of general purpose technologies (GPT) ${ }^{25}$. The main argument in this approach is the knowledge embodied in the product. Consequently, the PC represents to a larger extend a GPT than the other types of IT equipment are. Therefore, we find higher correlation of PCs and labor productivity than with any other type.

Moreover, network effects are a very important factor in computer related productivity. Standardisation processes lead to network externalities and thus to productivity effects. This also can explain our large PC productivity. This hypothesis is also supported by Harhoff and Moch (1996) who find significant price

25 See Helpman and Trajtenberg (1996) 
premia for compatibility for packaged PC database software that are positively correlated with the degree of compatibility.

\section{$5 \quad$ Summary and Conclusions}

This study presents some evidence about the use of IT in the service sector and about the effects of IT on the quality of service sector output as well as on productivity. The innovation survey data indicate that information technology has strong impacts on quality aspect of service innovations. We find plausible correlations between our qualitative output indicators and capital investment, R\&D, as well as human capital. Contrary to these results, IT seems to affect only some quality aspects of service sector products but not the productivity. Although a high percentage of innovating firms states to have realised productivity gains, managers of service firms seem to be less convinced by the productivity effect of IT investments. In this respect, our results are consistent with the pessimistic view on the productivity effects of IT found in other studies.

Possibly these results do not show significant productivity effects because we only use aggregate IT-investment and do not consider the type of equipment. Maybe it is more important what type of IT companies use than how much they invest. This argument is supported by the information technology survey data that exhibits large differences in the correlations between each type of IT and labor productivity. This result indicates that it is indeed very important to conduct more detailed analysis reflecting the structure of IT-investment to cover the full impact of IT.

Surely, automation is expected to bring productivity gains. However, we expect much more utility from obliterating business functions. Firms just started restructuring their IT. Most firms move along traditional lines and continue modelling traditional business functions with IT. This may prohibit the industry from reaping the benefits or might even have negative effects. As Paul David (1991) argues, the real benefits of electric power became visible after we had learned to replace central power distributed with transmission belts by locally powered devices. Therefore, we should expect that the real impacts of IT on productivity and product quality are still to come.

Finally, some caveats towards our results seem to be necessary. Since our data just consists of single cross-section of firms, our estimates may be biased because of omitted variables (e.g. R\&D or human capital) or simultaneity. Moreover, reversed causality may also be present. Therefore, future work should address these two issues. 


\section{References}

Ark, B. van (1996), Issues in Measurement and International Comparison Issues of Productivity An Overview, in: OECD (ed.), Industry Productivity. International Comparison and Measurement Issues, OECD Proceedings, Paris

Autor, D., Katz, L. F., Krueger A. B. (1996), Computing Inequality: Have Computers Changed the Labor Market?, NBER

Berndt, E. and Morrison, C. (1995), High-Tech Capital Formation and Economic Performance in U. S. Manufacturing Industries: An Exploratory Analysis, in: Journal of Econometrics 65, pp. 9-43

Berndt, E., Morrison, C. and Rosenblum, L. (1992), High-Tech Capital Formation and Labor Composition in U. S. Manufacturing Industries: An Exploratory Analysis, NBER, Cambridge, Mass. (Working Paper 4010)

Berndt, E. and Griliches, Z. (1993), Price Indexes for Microcomputers: An Exploratory Study, in Foss, M. et. al. (eds.), Price Measurements and their uses, The University of Chicago Press, Chicago.

Berndt, E., Griliches, Z. and Rappaport N. (1995), Econometric estimates of price indexes for personal computers in the 1990's, Journal of Econometrics, Vol. 68 , p. 243-268.

Black, S. and Lynch, L. (1996), How to Compete: The Impact of Workplace Practices and Information Technology on Productivity, The American Economic Review, Vol. LXXXVI, May 1996, p.263-267.

Blechinger, D. and Pfeiffer, F. (1996), Technological Change and Skill Obsolescence: The Case of German Apprenticeship Training, ZEW Discussion Paper 95-16, Mannheim

Brynjolfsson, E. and Hitt, L. (1996), Computers and Productivity Growth: Firm-Level Evidence, mimeo

Computer Science and Telecommunications Board (ed.) (1994), Information Technology in the Service Society: A Twenty-First Century Lever, National Academy Press, Washington, $\mathrm{DC}$

David, P. A. (1991), Computer and Dynamo: The Modern Productivity Paradox in a Not-TooDistant Mirror, in Technology and Productivity: The Challenge for Economic Policy, OECD, Paris.

Gault, F. D. (1996), Service Industries in the Innovation Survey, Background Paper for the Revision of the OSLO-manual, OECD-Document STI/EAS/STP/NESTI (96) 4, Paris.

Gordon, R. (1990): The Measurement of Durable Goods Prices, University of Chicago Press, Chicago

Gordon, R. (1996): Problems in the Measurement and Performance of Service-Sector Productivity in the United States, NBER, Cambridge, Mass. (Working Paper 5519)

Greenan, N. and Mairesse, J. (1996), Computers and Productivity in France: Some Evidence, NBER, Cambridge, Mass. (Working Paper 5836)

Griliches, Z. (ed.) (1992), Output Measurement in the Service Sectors, The University of Chicago Press, Chicago and London. (Studies in Income and Wealth, 56)

Griliches, Z. (1994), Productivity, R\&D, and the Data Constraint, American Economic Review, 84:1-23.

Griliches, Z. (1995), Comments on Measurement Issues in: Relating IT Expenditures to Productivity Growth, in Econ. Innov. New Techn., Vol. 3, pp. 317-321

Griliches, Z. and Mairesse, J. (1995), Computers and Productivity in France: Some Evidence, NBER, Cambridge, Mass. (Working Paper 5836)

Harhoff, D. and Moch, D. (1996), Price Indexes for PC Database Software and the Value of Code Compatibility, ZEW Discussion Paper 17-96 (forthcoming in Research Policy) 
Harhoff, D., Licht, G. et al. (1996), Innovationsaktivitäten kleiner und mittlerer Unternehmen. Ergebnisse des Mannheimer Innovationspanels, ZEW Schriftenreihe Bd. 8, Nomos, Baden-Baden.

Helpman, E. and Trajtenberg, M. (1996), Diffusion of General Purpose Technologies, NBER, Cambridge, Mass. (Working Paper 5773)

Höflich-Häberlein, L. and Häbler, H. (1989), Diffusion neuer Technologien und ihre Auswirkungen im privaten Dienstleistungssektor, in Schettkat, R. and Wagner, M. (eds.), Technologischer Wandel und Beschäftigung (Arbeitsmarktwirkungen moderner Technologien, 1), Berlin, Gruyter, pp. 71-144

Landau, R. (1989), Technology and Capital Formation, in: Jorgenson, D. and Landau, R., Technology and Capital Formation, MIT Press, Cambridge, Mass.

Landauer, T. K. (1995), The Trouble with Computers - Usefulness, Usability and Productivity, MIT Press, Cambridge, Mass.

Lehr, W. and Lichtenberg, F. (1996), Computer Use and Productivity Growth in Federal Government Agencies 1987 to 1992, NBER, Cambridge, Mass. (Working Paper 5616)

Licht, G., et al. (1996), Innovation in the Service Sector, Report to the German Ministry of Education, Science, Research and Technology, Mannheim and Karlsruhe.

Lichtenberg, F. (1995), The Output Contributions of Computer Equipment and Personnel: A FirmLevel Analysis, in Econ. Innov. New Techn., Vol. 3, pp. 201-217

Miles, I. and Matthews, M. (1992), Information Technology and the Information Economy, in: K. Robins (ed.), Understanding Information Technology, London

Nelson, R., Tanguay, T. and Patterson, C. (1994), A quality adjusted price-index for personal computers, Journal of the American Statistical Association, Vol. 12, No. 1, p.12-31.

OECD (1996), Industry Productivity: International Comparison and Measurement Issues, Paris

OECD (1997), Guidelines for Collecting and Interpreting Innovation Survey Data - The OSLO Manual, second edition, Paris (in print).

Oliner, S. and Sichel, D. (1994), Computers and Output Growth Revisited: How Big Is the Puzzle?, in: Brookings Papers on Economic Activity, 2

Siegel, D. and Griliches, Z, (1992), Purchased Services, Outsourcing , Computers, and Productivity in Manufacturing, in Z. Griliches(ed.) Output Measurement in the Service Sector, University of Chicago Press, Chicago 
Appendix 1: Summary statistics for the Innovation Survey Data Set

\begin{tabular}{|c|c|c|c|c|}
\hline \multirow[b]{2}{*}{ Variable } & \multicolumn{2}{|c|}{ Raw data } & \multicolumn{2}{|c|}{ Weighted data * } \\
\hline & Mean & Std. Dev. & Mean & Std. Dev. \\
\hline Labor productivity $* *$ & 1560.9150 & 16440.3700 & 1420.5110 & 23799.2200 \\
\hline Investment (excl. IT) per employee $* *$ & 14.3275 & 23.2332 & 16.1106 & 27.5136 \\
\hline IT-investment per employee $* *$ & 2.9028 & 5.1726 & 2.5304 & 4.9201 \\
\hline R\&D employment per employee [\%] & 1.5946 & 6.2944 & 1.4551 & 6.3107 \\
\hline Expenditures on professional education per employee $* *$ & 1.2608 & 2.7117 & 0.9906 & 2.1413 \\
\hline Share of high-qualified employees & 28.4031 & & 24.0783 & \\
\hline East-Germany & 0.3575 & & 0.2593 & \\
\hline \multicolumn{5}{|l|}{ (Base: Retail trade) } \\
\hline Wholesale trade & 0.1826 & & 0.2677 & \\
\hline Transport & 0.1452 & & 0.1083 & \\
\hline Banking / Insurance & 0.0898 & & 0.0046 & \\
\hline Other financial services & 0.0428 & & 0.0110 & \\
\hline Software & 0.0446 & & 0.0321 & \\
\hline Technical consultancy & 0.1023 & & 0.0573 & \\
\hline Other business services & 0.3093 & & 0.1977 & \\
\hline \multicolumn{5}{|l|}{ (Base category: less than 20 employees) } \\
\hline 20-49 employees & 0.2062 & & 0.1515 & \\
\hline 50-249 employees & 0.2775 & & 0.1318 & \\
\hline 250 and more employees & 0.1872 & & 0.0242 & \\
\hline
\end{tabular}

*Weights are the product of the inverse of a firm's inclusion probability and the inverse of the response rate.

** in DM 1000 


\section{Appendix 2:Innovation output dimensions and IT-investment in Services Seemingly unrelated regression results}

\begin{tabular}{|c|c|c|c|c|c|c|c|c|}
\hline \multirow[t]{2}{*}{ Endogenous variable } & \multicolumn{2}{|c|}{$\begin{array}{c}\text { Quality } \\
\text { (= Factor } 1)\end{array}$} & \multicolumn{2}{|c|}{$\begin{array}{c}\text { Enhancing customers } \\
\text { productivity } \\
(=\text { Factor } 2)\end{array}$} & \multicolumn{2}{|c|}{$\begin{array}{l}\text { Productivity } \\
\text { (=Factor 3) }\end{array}$} & \multicolumn{2}{|c|}{$\begin{array}{l}\text { Regulation, } \\
\text { Standards } \\
\text { (= Factor } 4)\end{array}$} \\
\hline & coef. & $\mathrm{t}$-value & coef. & t-value & coef. & t-value & coef. & t-value \\
\hline Non-IT investment & 0,0024 & 2,72 & 0,0058 & 7,10 & 0,0015 & 1,45 & 0,0057 & 7,32 \\
\hline IT-investment & 0,0110 & 2,50 & 0,0043 & 1,09 & 0,0071 & 1,41 & $-0,0031$ & $-0,79$ \\
\hline$R \& D$ & 0,0018 & 0,59 & 0,0103 & 3,76 & 0,0088 & 2,55 & 0,0065 & 2,44 \\
\hline Professional education & 0,0209 & 1,89 & 0,0366 & 3,63 & 0,0307 & 2,43 & 0,0205 & 2,11 \\
\hline East-Germany & 0,1368 & 2,68 & $-0,2938$ & $-6,32$ & 0,0520 & 0,89 & $-0,1486$ & $-3,32$ \\
\hline _cons & $-0,2884$ & $-5,54$ & $-0,2835$ & $-5,98$ & $-0,0544$ & $-0,91$ & $-0,0032$ & $-0,069$ \\
\hline \multicolumn{9}{|c|}{ test statistics } \\
\hline Industry dummies & $\mathrm{F}(7,4888)=$ & 4,00 & $\mathrm{~F}(7,4888)=$ & 15,58 & $\mathrm{~F}(7,4888)=$ & 1,38 & $\mathrm{~F}(7,4888)=$ & 3,81 \\
\hline Size dummies & $F(3,4888)=$ & 0,41 & $\mathrm{~F}(3,4888)=$ & 0,91 & $\mathrm{~F}(3,4888)=$ & 0,41 & $\mathrm{~F}(3,4888)=$ & 3,17 \\
\hline
\end{tabular}

Number of observations: 1238

Breusch-Pagan-Test of independence: $\operatorname{chi} 2(6)=314,739$

Endogenous variables are based on factor score derived from a factor analysis (see Table 2). 
Appendix 3: Summary statistics for the IT-Survey Data Set: Service Sector

\begin{tabular}{|c|c|c|c|c|c|c|c|c|c|}
\hline & Overall & $\begin{array}{c}\text { Wholesale } \\
\text { Trade }\end{array}$ & $\begin{array}{l}\text { Retail } \\
\text { Trade }\end{array}$ & Transport & $\begin{array}{l}\text { Banking, } \\
\text { Insurance }\end{array}$ & $\begin{array}{c}\text { Financial } \\
\text { Services }\end{array}$ & Software & Consulting & Others \\
\hline $\log ($ Labor Productivity)* & $\begin{array}{l}12.428 \\
(1.372) \\
\end{array}$ & $\begin{array}{l}13.094 \\
(1.258) \\
\end{array}$ & $\begin{array}{l}12.602 \\
(0.802) \\
\end{array}$ & $\begin{array}{l}12.428 \\
(1.324)\end{array}$ & $\begin{array}{l}14.899 \\
(1.370) \\
\end{array}$ & $\begin{array}{l}12.001 \\
(1.150) \\
\end{array}$ & $\begin{array}{l}12.214 \\
(0.761)\end{array}$ & $\begin{array}{l}11.481 \\
(0.990)\end{array}$ & $\begin{array}{l}12.086 \\
(1.278) \\
\end{array}$ \\
\hline $\log ($ Capital $) *$ & 5.524 & 4.996 & 4.656 & 5.719 & 5.579 & 4.712 & 7.065 & 6.261 & 6.011 \\
\hline $\log ($ Material)* & 4.692 & 6.418 & 5.390 & 4.693 & 4.451 & 4.092 & 4.388 & 4.566 & 4.156 \\
\hline $\log ($ Mainframe Terminals)* & $\begin{array}{l}-0.017 \\
(0.203)\end{array}$ & $\begin{array}{l}-0.004 \\
(0.030)\end{array}$ & $\begin{array}{c}0 \\
(0)\end{array}$ & $\begin{array}{l}-0.073 \\
(0.455)\end{array}$ & $\begin{array}{c}0 \\
(0)\end{array}$ & $\begin{array}{c}-0.064 \\
0.450\end{array}$ & $\begin{array}{l}-0.125 \\
0.353\end{array}$ & $\begin{array}{c}0 \\
(0)\end{array}$ & $\begin{array}{l}-0.004 \\
(0.052)\end{array}$ \\
\hline $\log ($ Midrange Terminals)* & $\begin{array}{l}-0.298 \\
(0.849) \\
\end{array}$ & $\begin{array}{l}-0.249 \\
(0.662)\end{array}$ & $\begin{array}{l}-0.069 \\
(0.323) \\
\end{array}$ & $\begin{array}{l}-0.288 \\
(0.664)\end{array}$ & $\begin{array}{l}-0.432 \\
(0.859)\end{array}$ & $\begin{array}{l}-0.182 \\
(0.695) \\
\end{array}$ & $\begin{array}{l}-0.519 \\
(1.467) \\
\end{array}$ & $\begin{array}{l}-0.148 \\
(0.495) \\
\end{array}$ & $\begin{array}{l}-0.420 \\
(1.058) \\
\end{array}$ \\
\hline $\log ($ UNIX Workstations)* & $\begin{array}{l}-0.320 \\
(1.080) \\
\end{array}$ & $\begin{array}{l}-0.243 \\
(0.926)\end{array}$ & $\begin{array}{l}-0.286 \\
(0.886) \\
\end{array}$ & $\begin{array}{l}-0.358 \\
(1.145)\end{array}$ & $\begin{array}{l}-0.509 \\
(1.202)\end{array}$ & $\begin{array}{l}-0.179 \\
(0.751)\end{array}$ & $\begin{array}{l}-0.137 \\
(0.388)\end{array}$ & $\begin{array}{l}-0.692 \\
(1.355) \\
\end{array}$ & $\begin{array}{l}-0.324 \\
(1.206) \\
\end{array}$ \\
\hline $\log (\mathrm{PC} \text { and } \mathrm{MACs})^{*}$ & $\begin{array}{l}-1.410 \\
(1.285)\end{array}$ & $\begin{array}{l}-1.2647 \\
(1.098)\end{array}$ & $\begin{array}{l}-1.280 \\
(0.963)\end{array}$ & $\begin{array}{l}-1.768 \\
(1.158)\end{array}$ & $\begin{array}{l}-0.810 \\
(1.019)\end{array}$ & $\begin{array}{l}-1.977 \\
(1.461)\end{array}$ & $\begin{array}{l}-0.502 \\
(0.755)\end{array}$ & $\begin{array}{l}-0.505 \\
(1.028)\end{array}$ & $\begin{array}{l}-1.502 \\
(1.388)\end{array}$ \\
\hline $\begin{array}{c}\text { size class } 1 \\
\text { 1-19 Employees }\end{array}$ & 0.4303 & 0.4545 & 0.6578 & 0.3076 & 0.2800 & 0.3265 & 0.3750 & 0.5000 & 0.4000 \\
\hline $\begin{array}{c}\text { size class } 2 \\
\text { 20-49 Employees } \\
\end{array}$ & 0.2362 & 0.3272 & 0.2105 & 0.4102 & 0.2800 & 0.2448 & 0.3750 & 0.3636 & 0.1600 \\
\hline $\begin{array}{c}\text { size class } 3 \\
\text { 50-249 Employees } \\
\end{array}$ & 0.2299 & 0.1636 & 0.1315 & 0.2307 & 0.4000 & 0.3673 & 0.2500 & 0.1363 & 0.2400 \\
\hline $\begin{array}{c}\text { size class } 4 \\
>=250 \text { Employees }\end{array}$ & 0.1033 & 0.0545 & 0 & 0.0512 & 0.0400 & 0.0612 & 0 & 0 & 0.2000 \\
\hline Wholesale /Trade & 0.1160 & & & & & & & & \\
\hline Retail /Trade & 0.1603 & & & & & & & & \\
\hline Transport & 0.0822 & & & & & & & & \\
\hline Banking /Insurance & 0.0527 & & & & & & & & \\
\hline Financial Services & 0.1033 & & & & & & & & \\
\hline Software /Consulting & 0.0632 & & & & & & & & \\
\hline Others & 0.4219 & & & & & & & & \\
\hline
\end{tabular}

$\mathrm{N}=474$; Mean (STD. Dev.) 